\title{
The sense of meaning of life as a factor protecting lower-secondary school youth against the fear of missing out
}

\author{
Poczucie sensu życia jako czynnik chroniący młodzież gimnazjalną \\ przed obawą przed byciem pominiętym
}

\author{
1 Department of Clinical Psychology of Children and Adolescents, The Maria Grzegorzewska University, Warsaw, Poland \\ ${ }^{2}$ Department of Child and Adolescent Health, Institute of Mother and Child, Warsaw, Poland \\ ${ }^{3}$ Department of Humanization of Medicine and Sexology, Faculty of Medicine and Health Sciences, University of Zielona Góra, Zielona Góra, Poland \\ Correspondence: Dorota Zawadzka, PhD, Assistant Professor at the Maria Grzegorzewska University (APS), Institute of Psychology, Department of Clinical Psychology of Children and Adolescents, \\ Szzzęśliwicka 40,02-353 Warsaw, Poland, e-mail: dzawadzka@aps.edu.pl; Senior Assistant - Specialist at Institute of Mother and Child, Department of Child and Adolescent Health, \\ Kasprzaka 17a, 01-211 Warsaw, Poland, e-mail: dorzawadzka@imid.med.pl
}

\author{
'Zakład Psychologii Klinizznej Dzieci i Młodzieży, Akademia Pedagogiki Specjalnej im. Marii Grzegorzewskiej, Warszawa, Polska \\ 2 Zakład Zdrowia Dzieci i Młodzieży, Instytut Matki i Dziecka, Warszawa, Polska \\ ${ }^{3}$ Katedra Humanizacji Medycyny i Seksuologii, Wydział Lekarski i Nauk o Zdrowiu, Uniwersytet Zielonogórski, Zielona Góra, Polska \\ Adres do korespondencji: Dorota Zawadzka, Adiunkt w Zakładzie Psychologii Klinicznej Dzieci i Młodzieży, Akademia Pedagogiki Specjalnej im. Marii Grzegorzewskiej, ul. Szzzę́liwicka 40, 02-353 Warszawa, \\ e-mail: dzawadzk@@aps.edu.pl; Starszy Asystent - Specjalistaw Zakładzie Zdrowia Dzieci i Młodzieży, Instytut Matki i Dziecka, ul. Kasprzaka 17a, 01-211 Warszawa, e-mail: dorzawadzka@imid.med.pl
}

\begin{abstract}
Aim: The aim of the paper was to investigate the relationship between the level of the sense of meaning life and mental wellbeing as well as the fear of missing out in relation to gender, social class and family affluence. Method: The study used data from a pilot study conducted in Poland in 2017 before the main HBSC 2018 survey (Health Behaviour in School-aged Children). An anonymous survey was conducted in lower-secondary schools, in accordance with the international HBSC research protocol. The analyses were performed in a group of 539 students (46\% of girls) attending grades 1-3 of lowersecondary schools (mean age $14.75 \pm 0.99$ years). The following tools were used in this research: Fear of Missing Out Scale (FOMO), Purpose in Life Test (PiL), Well-Being Index (WHO-5), and Family Affluence Scale (FAS). The results of univariate non-parametric analyses concerning the mean level of the above indices were presented. A generalised linear model for FOMO as a dependent variable was used with stepwise introduction of variables as a part of multivariate analysis. Results: Students with a high level of PiL showed a much higher life satisfaction and a lower level of FOMO than those with a low level of PiL. PiL increased in more affluent families. A significant correlation between PiL and FOMO was found in both genders, while a significant correlation between PiL and WHO-5 was shown only in girls. In the final model, only PiL was found to be a significant predictor of FOMO, while gender, grade, WHO- 5 and FAS were rejected. Conclusions: Our study has some practical implications, such as how to avoid problematic social media use. Classes devoted to the meaning of life and the place in life should be organised.
\end{abstract}

Keywords: meaning of life, fear of missing out, mental well-being, family affluence, school youth

Streszczenie Cel badania: Celem pracy jest zbadanie nie tylko związku między poziomem poczucia sensu życia a samopoczuciem psychicznym, ale także lęku przed utratą w zależności od płci, poziomu klasy społecznej i zamożności rodziny. Metoda: W badaniu wykorzystano dane z badania pilotażowego przeprowadzonego w Polsce w 2017 roku przed głównym badaniem HBSC 2018 (Zachowania zdrowotne u dzieci w wieku szkolnym). Anonimową ankietę przeprowadzono w szkołach średnich I stopnia zgodnie z międzynarodowym protokołem badawczym HBSC. Analizy dotyczyły grupy 539 uczniów (46\% dziewcząt) uczęszczających do klas 1-3 szkół gimnazjalnych (średnia wieku 14,75 $\pm 0,99$ ). W badaniach wykorzystano następujące narzędzia: strach przed pominięciem/odłączeniem (Fear of Missing Out Scale, FOMO), Test Sensu Życia (Purpose in Life Test, PiL), wskaźnik dobrostanu (Well-Being Index, WHO-5), skala zamożności rodziny (Family Affluence Scale, FAS). Przedstawiono wyniki jednowymiarowych analiz nieparametrycznych, które dotyczą średniego poziomu powyższych wskaźników. W ramach analizy wielowymiarowej uogólniony model liniowy dla FOMO 
jako zmiennej zależnej zastosowano przy stopniowym wprowadzaniu zmiennych. Wyniki: Uczniowie z wysokim poziomem poczucia sensu życia wykazywali znacznie wyższą satysfakcję z życia i niższy poziom obawy przed byciem pominiętym niż uczniowie z niskim poziomem poczucia sensu życia. Wskaźnik poczucia sensu życia wzrósł w bardziej zamożnych rodzinach. Istotna korelacja między poczuciem sensu życia i obawą przed byciem pominiętym jest zachowana u obu płci, podczas gdy istotna korelacja między poczuciem sensu życia i dobrostanem psychicznym - tylko u dziewcząt. W ostatecznym modelu tylko poczucie sensu życia pozostało istotnym predyktorem obawy przed byciem pominiętym, podczas gdy płeć, klasa, dobrostan psychiczny i zamożność rodziny zostały odrzucone. Wnioski: Niniejsze badanie wskazuje na pewne praktyczne implikacje, jak uniknąć problematycznego korzystania z mediów społecznościowych. Należy zorganizować zajęcia związane ze znalezieniem sensu i miejsca w życiu.

Słowa kluczowe: poczucie sensu życia, obawa przed byciem pominiętym, dobrostan psychiczny, zamożność rodziny, młodzież

\section{INTRODUCTION}

\section{The sense of meaning of life}

$\mathrm{V}$ ictor Emil Frankl (1959), who is considered a pioneer in researching the sense of meaning of life, emphasised the significance of finding values in life in his works. His works constituted a bold dissent against behaviourist and psychodynamic paradigms that had dominated psychological theories (Steger et al., 2011). The contemporary concepts of purpose in life are often combined with Frankl's classic texts $(1967,1985,1972,2014)$, underlining the component of a strong sense of meaning and purpose in life. The concept of the meaning of life is associated with such notions as internal strength, internal or spiritual freedom and personal worth, which may result in a greater ability to tolerate situations which are difficult - and even extreme - for mental and physical health. The sense of meaning of life is one of the six key elements of well-being along with autonomy, personal development, environmental mastery, positive relationships and self-acceptance (Carol D. Ryff's model) (1989). Baumeister (1991) concluded that we can refer to four main needs, the fulfilment of which makes it possible to declare life meaningful in our search of a meaningful life. They are in the form of four templates of motivation for human activity aimed at understanding the sense of existence. These needs may be defined as purposefulness, values, self-efficacy and self-esteem. It was found that the meaning of life has a stronger correlation with the positive rather than the negative dimensions of mental well-being, which suggests a salutogenic approach to research on mental health (Zika and Chamberlain, 1992).

\section{Mental well-being}

There has been a growing interest in mental well-being among sociologists, economists, psychologists and anthropologists for the last few years. From both theoretical and pragmatic point of view, the concept of mental well-being is very important for social sciences and individual life strategies (Niśkiewicz, 2016). The definition of mental well-being encompasses the affective and the cognitive aspect. The af- frequency of experiencing positive emotions and moods. The cognitive aspect is the assessment of one's life as satisfactory (overall and at the level of its individual elements) (Czerw and Babiak, 2010). Many authors emphasise that satisfaction appears when a person positively evaluates the quality of their life (Boniwell and Henry, 2007). Mental wellbeing may be defined as the effect of a cognitive and emotional assessment of one's life which is composed of a high level of fulfilment and life satisfaction. When a person notices that positive experiences and pleasant emotions as well as a low level of negative experiences and moods prevail in their environment, then they may conclude that mental well-being is a value that is relevant to them (KasperekGolimowska, 2012). However, it should be noted that mental well-being is not something that is given and permanent, and for this reason it is important to constantly work on maintaining it. Mental well-being, "also referred to as 'personal', is described in six dimensions, such as: 1) self-acceptance, 2) personal development, 3) purpose in life, 4) control of the environment, 5) autonomy, 6) positive relationships with others" (Cieślińska, 2013, p. 102). There should be focus on each of these areas to analyse whether they are present in an individual's life and whether all of them are fulfilled in a positive way. Diener (2000) proposed a three-factor structure of subjective well-being. The first two are affective: positive (e.g. joy, pride) and negative (e.g. envy, guilt), while the third one is a cognitive one (e.g. work, family, school) (Diener, 1984).

\section{Fear of missing out}

Scientific and technical development, the possibility of fast travel, and almost unlimited access to information made the world shrink to a "symbolic global village" (Gajda, 2007). The phenomenon of globalisation, according to Roland Robertson (1992), consists in "compressing, squeezing, concentrating facts, norms, values coming from various national cultures, different stages of development, intellectual levels and axiological alignments." It is a process which penetrates various spheres of life and arouses the interest of both its participants and the observers of contemporary reality. Adopting this point of view brings awareness of connections with people from other countries, but also of problems which particularly affect the world (Borzucka-Sitkiewicz 
and Leksy, 2017). The Internet has become an indispensable element of everyday life. Aboujaoude (2012) points out that all people are currently addicted to this medium to a greater or lesser extent; if not clinically, then functionally and practically. Recent attempts to detect mental predecessors of pathological Internet use indicate a relatively new psychological phenomenon described as the "fear of missing out" (FOMO). FOMO is defined as the fear of missing out on an opportunity for social interaction, a novel experience, a profitable investment, or other satisfying events (Beyens et al., 2016). The mediating role of FOMO, combining deficits in psychological needs with excessive use of social media, was evaluated in several studies. For example, Abel et al. (2016) described FOMO as an overwhelming need to be in two or more places at the same time, encumbered by the fear that the lack of control may affect the feeling of happiness. The results suggest significant differences in the use of social media at all measured levels of FOMO (Przybylski et al., 2013). One of the studies showed that individuals displaying a lower level of satisfaction of basic psychological needs related to competences (efficacy), autonomy (sensible choice) and belonging (relationships with others), reported higher levels of FOMO and an increased behavioural engagement in social media. Beyens et al. (2016) indicated that increased needs of belonging and popularity may also be additionally correlated with the use of Facebook. FOMO played a mediating role in these correlations. Moreover, Lai et al. (2016) studied the neurobiological correlates of FOMO in response to social exclusion and social integration. The findings indicated that FOMO was associated with a greater sensitivity to experiences related to social integration rather than social exclusion. By using social media, young people may satisfy their need of belonging and expose themselves to a serious risk of experiencing FOMO in relation to relevant shared experiences. Adolescents with psychopathological problems (especially anxiety and depression) may be affected by negative repercussions mediated by FOMO and the frequent use of social media. FOMO mediates the link between psychopathological symptoms and the negative effects of using social media through mobile devices. Adolescents who report the symptoms of FOMO may use social media to replenish these resources through attempts to make contact with other people through the Internet (Oberst et al., 2017). In the light of the available knowledge, no research on FOMO has been conducted so far in the context of the sense of meaning of life and general well-being.

\section{THE AIM OF THE STUDY AND RESEARCH QUESTIONS}

The aim of the paper was to investigate the relationship between the sense of meaning of life and mental well-being as well as fear of missing out in relation to gender, social class and family affluence.

1. Are such elements as gender and affluence associated with mental well-being, the sense of meaning of life and FOMO?
2. What is the relationship between the sense of meaning of life and the level of well-being?

3. What is the relationship between the level of the sense of meaning of life and the level of FOMO?

4. Which of the three investigated variables: mental wellbeing, the sense of meaning of life, level of affluence, can be considered to be the most essential predictor of FOMO?

\section{MATERIAL AND METHODS}

The study assessed data from a pilot study for a HBSC project (Health Behaviour in School-aged Children) conducted in the 2017-2018 school year by the Institute of Mother and Child. An anonymous survey study was conducted on site at schools. The same procedure was followed, in accordance with the international HBSC research protocol (Mazur, 2015). Randomly selected students attending 25 forms in 14 schools located in three voivodeships took part in the research. To get an average for Polish population, we adopted the strategy of aiming at middle-sized cities (about 30,000 citizens) from randomly chosen areas. Response rate calculated at students' level was $89.8 \%$. The study was approved by the Bioethics Committee of the Institute of Mother and Child (Opinion No. 17/2017 dated on $30^{\text {th }}$ March 2017) and by the school principals. Consents were obtained from respondents' parents. The analyses were conducted in a group of 539 students (46\% girls) attending grades $1-3$ of lower-secondary schools (mean age $=14.75 \pm 0.99$ years).

The following issues were analysed in the study:

1. Fear of missing out (FOMO). Przybylski et al. (2013) developed a scale composed of 10 items. The tool was validated based on a representative sample of 2,079 adults. The scale was designed to reflect fears, worries and anxieties that may be experienced by people due to events, experiences and conversations in their extended social environment (or outside it). Our study showed a high reliability of the FOMO scale (Cronbach's alpha $=0.763)$. An example of a statement on the FOMO scale would be: I am worried when I find out that my friends are having a good time without me. Each of the ten positions is rated on a 4 -point scale from 0 (completely false) to 3 (completely true). Treating 10 questions as one scale was considered acceptable. The scores range from 0 to 30 , where a higher score means a higher level of FOMO.

2. The sense of meaning of life was investigated using the Purpose in Life Test (PiL) by J.C. Crumbaugh and L.T. Maholick (1964), in the authorised translation by Z. Płużek (Popielski, 1987). The study used a shorter, single-factor version composed of 4 statements rated on a 7-point scale and referring directly to having a purpose and finding a meaning and a role in life, proposed by Schulenberg et al. (2016). A summary index 
with a range of 0-24 points was developed. In general, the higher the score on the scale, the higher the level of the sense of meaning of life among the surveyed adolescents. For the purpose of the study, the sense of meaning of life was classified into three categories: low (0-12 points), average (13-20 points) and high (21-24 points). This version comprised four statements, e.g.: In life: I have no goals and I aspire to nothing (1) - I have very clear goals and aspirations (7). The cited studies showed a high reliability of the scale (Cronbach's alpha $=0.862$ ) and its homogeneity (one factor explains $71 \%$ of the total variability; the correlation between the questions and the general scale ranged from 0.820 to 0.874 ).

3. Feeling good as a metric of mental well-being was measured using the 5-item WHO-5 scale (WHO-5 WellBeing Index). The statements are based on positive mood, e.g. I have felt cheerful and in good spirits, vitality, e.g. I have felt active and vigorous, and having and pursuing hobbies, e.g. My daily life has been filled with things that interest me. Each of the 5 items is rated on the 6-point Likert scale from 0 (never) to 5 (all the time). The scores range from 0 to 25 , where higher numbers mean better well-being. Our studies showed a high reliability of the scale (Cronbach's alpha $=0.882)$ and its homogeneity (one factor explains $68 \%$ of the total variability; the correlation between the questions and the general scale ranged from 0.794 to 0.846 ).

4. Family affluence was evaluated using the FAS (Family Affluence Scale). The FAS scale is used in the HBSC surveys as a reliable measure of the socio-economic status of the family (Currie et al., 2014; Mazur, 2013). We used the third version of the scale (FAS III), which comprises 6 questions. They relate to: the number of cars in the family; whether the students have their own room; the number of computers in the family; the number of bathrooms in the household; having a dishwasher; and family trips abroad for summer and winter holidays. The range for this scale is $0-13$ points. For the needs of this study, the results of the scale were classified into 3 categories of families: poor ( $0-6$ points), average (7-9 points) and affluent (10-13 points).

The results of univariate analyses for the mean level of FOMO, the level of the sense of meaning of life, and the level of well-being are presented. Non-normal distribution of all key variables was confirmed. Therefore, nonparametric tests (Mann-Whitney and Kruskal-Wallis) were used for the analyses, along with Spearman's coefficients of correlation. As an element of multivariate analysis, the generalised linear model was used with hierarchi$\mathrm{cal}$ introduction of variables. The general FOMO index was the dependent variable in the model. The regression model also included gender and grade (1-3) of lower secondary school as controlled variables. In all the analyses, $p<0.05$ was adopted as the level of significance. We used

\begin{tabular}{|l|c|c|c|}
\hline \multirow{2}{*}{} & \multicolumn{3}{|c|}{ Outcome scale } \\
\cline { 2 - 4 } & WH0-5 & FOM0 & PiL \\
\hline Boys & $14.50(5.8)$ & $10.51(5.4)$ & $16.41(5.8)$ \\
\hline Girls & $13.09(5.5)$ & $11.01(5.2)$ & $16.4(5.4)$ \\
\hline Total & $13.7(5.6)$ & $10.78(5.3)$ & $16.41(5.59)$ \\
\hline $\boldsymbol{p}$ & $\mathbf{0 . 0 0 3}$ & 0.448 & 0.776 \\
\hline \multicolumn{4}{|c|}{ Grade } \\
\hline Grade 1 & $14.85(5.3)$ & $10.49(5.7)$ & $16.80(5.4)$ \\
\hline Grade 2 & $13.34(5.8)$ & $10.49(5.2)$ & $15.74(6.0)$ \\
\hline Grade 3 & $12.83(5.7)$ & $11.42(5.1)$ & $16.68(5.1)$ \\
\hline Total & $13.70(5.7)$ & $10.79(5.3)$ & $16.39(5.6)$ \\
\hline $\boldsymbol{p}$ & $\mathbf{0 . 0 0 3}$ & 0.081 & 0.268 \\
\hline \multicolumn{5}{|c|}{ Family affluence } \\
\hline Poor & $12.78(5.9)$ & $11.09(5.7)$ & $15.55(5.8)$ \\
\hline Average & $13.78(5.5)$ & $10.73(5.3)$ & $16.41(5.1)$ \\
\hline Well-off & $14.49(5.7)$ & $10.68(5.0)$ & $17.31(5.8)$ \\
\hline Total & $13.73(5.7)$ & $10.81(5.3)$ & $16.45(5.5)$ \\
\hline $\boldsymbol{p}$ & 0.061 & 0.768 & $\mathbf{0 . 0 0 6}$ \\
\hline
\end{tabular}

Tab. 1. Mean scores of Well-Being Index, Fear of Missing Out Scale and Purpose in Life Test by gender, grade and family affluence (SD)

\section{RESULTS}

\section{Study group}

Three grades of lower-secondary school (1-3) were equally represented in the study sample $(33.5 \%, 34.0 \%$, $32.5 \%$, respectively). According to the FAS scale, families considered as less affluent accounted for $25.1 \%$, families at an average level of affluence accounted for $46.7 \%$. Statistically significant differences were found in mental well-being measured with the WHO-5 scale depending on gender and age. There were also statistical differences in the sense of the meaning of life related to family affluence (Tab. 1).

\section{FOMO and well-being depending on the level of the sense of meaning of life}

The analyses showed a moderately positive correlation between the level of the sense of meaning of life and the level of well-being $(r=0.526 ; p<0.001)$ and a weak negative correlation between the level of the sense of meaning of life and the level of FOMO $(r=-0.199 ; p<0.001)$. A weak negative correlation was also found between the level of well-being and the level of FOMO $(r=-0.185$; $p<0.001$ ).

Upon categorisation of the PiL scale, a statistically significant association was also found between the level of the sense of meaning of life, mental well-being and FOMO (Tab. 2). Respondents with a high level of PiL showed much higher life satisfaction measured by the WHO-5 score and a lower level of FOMO compared 


\begin{tabular}{|l|c|c|}
\hline \multirow{2}{*}{$\begin{array}{c}\text { Sense of meaning } \\
\text { (PiL) }\end{array}$} & \multicolumn{2}{|c|}{ Outcome scale } \\
\cline { 2 - 3 } & WHO-5(SD) & FOMO (SD) \\
\hline Low & $9.66(5.4)$ & $11.99(5.7)$ \\
\hline Average & $13.73(4.9)$ & $11.00(5.0)$ \\
\hline High & $17.52(4.9)$ & $9.24(5.2)$ \\
\hline Total & $13.71(5.7)$ & $10.80(5.3)$ \\
\hline $\boldsymbol{p}$ & $<\mathbf{0 . 0 0 1}$ & $<\mathbf{0 . 0 0 1}$ \\
\hline \multicolumn{3}{|c|}{ Boys } \\
\hline Low & $10.23(5.7)$ & $11.36(5.8)$ \\
\hline Average & $14.84(5.0)$ & $10.32(5.2)$ \\
\hline High & $17.86(5.8)$ & $9.82(5.3)$ \\
\hline Total & $14.50(5.8)$ & $10.43(5.4)$ \\
\hline $\boldsymbol{p}$ & 0.213 & $<\mathbf{0 . 0 0 1}$ \\
\hline \multicolumn{3}{|c|}{ Girls } \\
\hline Low & $9.27(5.1)$ & $11.09(5.7)$ \\
\hline Average & $12.96(4.6)$ & $10.73(5.3)$ \\
\hline High & $17.21(4.9)$ & $10.68(5.0)$ \\
\hline Total & $13.13(5.5)$ & $11.07(5.3)$ \\
\hline $\boldsymbol{p}$ & $<\mathbf{0 . 0 0 1}$ & $<\mathbf{0 . 0 0 1}$ \\
\hline
\end{tabular}

Tab. 2. Means scores of Well-Being Index and Fear of Missing Out Scale in relation to the purpose in life measured by the PiL scale

to those with a low level of PiL. A significant association between PiL and FOMO was found in both genders, while a significant relationship with WHO-5 was found only in girls.

When investigating FOMO determinants, age, gender and family affluence were introduced at the first stage; Well-Being Index at the second stage; PiL at the third stage. The influence of the demographic and socio-economic characteristics turned out to be insignificant in all 3 models. After introducing mental well-being into the second model, it turned out that the variable is an important predictor of FOMO $(p<0.001)$. When another variable (PiL) was introduced into the third model, it turned out to be the key predictor $(p<0.001)$. In the third model, the influence of life satisfaction was insignificant $(p=0.009)$ (Tab. 3).

\section{DISCUSSION}

The aim of this paper was to present the association between the level of the sense of meaning of life, mental wellbeing and FOMO in the context of gender, age and family affluence of the surveyed students. Data collected from 539 lower-secondary school students were analysed statistically. In the course of the analyses, answers were sought for the 4 research questions.

As for the first question, relating to the impact of the demographic characteristics, a statistically significant association was found between gender, age and mental wellbeing as well as between the sense of meaning of life and the level of family affluence. We obtained similar results in our previous research (Zawadzka et al., 2017). A high level of the sense of meaning of life was almost 1.5-times more likely to be found in students from affluent and moderately affluent families compared to poor families. Similar results were obtained by Mazur et al. (2009). In the entire group of Polish 11-18-year-olds surveyed in 2005-2006, 23\% were unsatisfied with their lives. It was found that the percentage decreased with increasing family affluence. In the group of the poorest families (0-1 points in the FAS scale), $37.8 \%$ of adolescents were unsatisfied with life compared to $13.6 \%$ in the most affluent group. In general, in the logistic regression model corrected for age and gender, the relative risk of being unsatisfied with life, resulting from extreme poverty, was more than three times higher compared to the group of non-poor adolescents (odds ratio, OR $=3.34$; $95 \%$ confidence interval, $\mathrm{CI}<2.68-4.17>$ ). Therefore, it was found that age is an important factor modifying the correlation between life satisfaction and family affluence (Mazur et al., 2009).

The second research question concerned the association between the level of the sense of meaning of life and the level of well-being. A moderately positive association was observed between the level of the sense of meaning of life and the level of mental well-being. Previous research showed that life satisfaction increased the likelihood of a high level of the sense of meaning of life almost

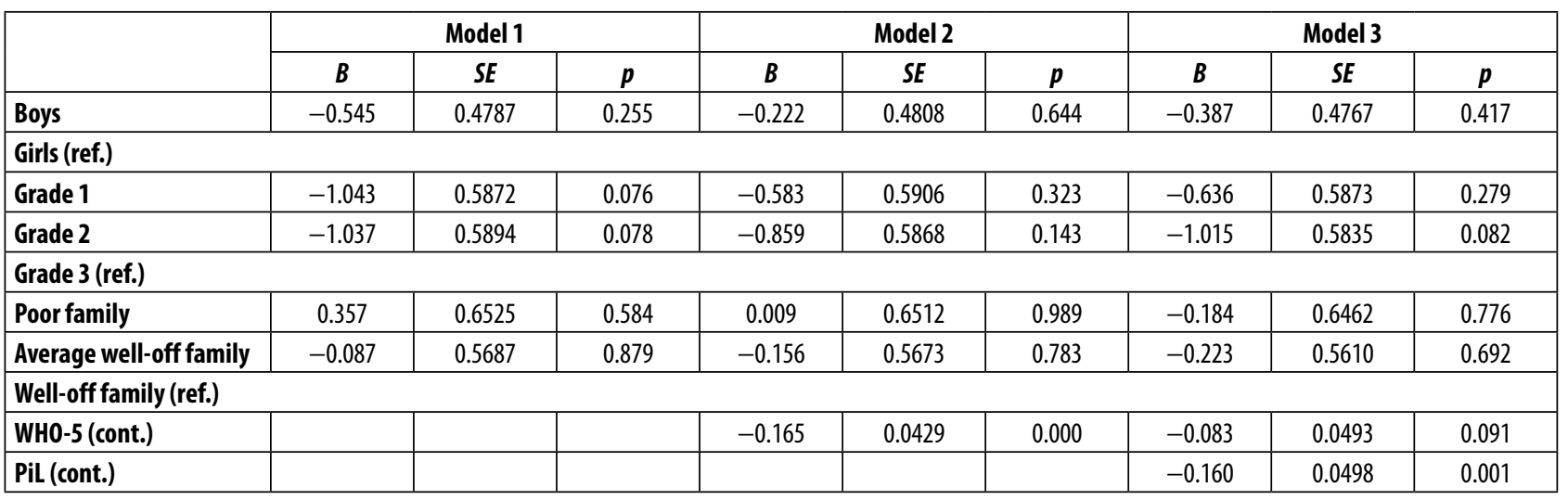

Tab. 3. Results of the generalised linear regression model for FOMO determinants 
fivefold ( $\mathrm{OR}=4.70)$ vs. unsatisfied students (Zawadzka et al., 2017). Similar results were obtained also by the same authors in a study on the sense of meaning of life, health self-assessment and school performance of students (Zawadzka et al., 2018, 2016). It should be emphasised that Zika and Chamberlain (1992) demonstrated a high correlation between PiL and indicators of mental well-being already three decades ago.

The third question pertained to the correlation between the level of the sense of meaning of life and the level of FOMO. A weak negative correlation was identified. This means that a stronger sense of the meaning of life coexists with a decreasing level of FOMO. Przybylski et al. (2013) also reported higher levels of FOMO in individuals displaying lower satisfaction of basic psychological needs relating to competences (efficacy), autonomy (sensible choice) and kinship (combined with each other). The study also verified the correlations between FOMO and mental well-being. It was also found that FOMO may be associated with negative experiences. The study showed a negative correlation between FOMO, general mood and general life satisfaction. These outcomes corroborate previous research indicating the existence of such social and emotional states as suffering and loneliness. The use of social media also correlates with FOMO (Burke et al., 2010; Lampe et al., 2007).

The fourth research question related to identifying the strongest predictors of FOMO. Our analyses showed that it was the sense of meaning of life. Therefore, the study indicates that this construct should be taken into account in the research on the mental well-being of children and adolescents. As there are no studies exploring the direct correlation between FOMO and the sense of meaning of life, it was decided that the recent studies conducted by Stead and Bibby (2017) in a group of 495 women aged 18-30 years should be included in the analyses. According to these authors, both FOMO and the problematic use of the Internet contributed significantly to subjective general mood. FOMO and problematic Internet use were negatively correlated with good emotional mood and personal well-being, which translate also to the level of the sense of meaning of life. Similar research was also conducted by Milyavskaya et al. (2018). FOMO seems to be a common experience and has recently become part of everyday speech and often appears in the media. This article describes a multi-stage empirical study on FOMO. School registers and end-of-term grades provided data on the short-term and long-term consequences of experiencing FOMO. The results showed, among other things, that students often experience FOMO, in particular in the afternoon and at the end of the week as well as when performing the tasks required of them, such as studying or working. Experiencing FOMO was more frequently connected with negative performance, both on a daily basis and in the course of the term, as well as with tiredness, stress, physical symptoms and sleep deprivation,
This paper can be considered innovative as it combines the sense of meaning of life and FOMO as a relatively recently explored phenomenon. The sense of meaning of life may be considered a protective factor against problematic Internet use, which also minimises the risk of exposure to cyberbullying. Individuals with a sense of their own worth, showing a high level of the sense of meaning of life, do not need to raise their own self-esteem through constant presence in the social media.

Undoubtedly, the average-sized sample of 539 students is a limitation of the present study. However, it was a pilot study in which new scales were tested.

Considering our findings, we suggest organising classes in schools to promote non-material values, along with coaching and mentoring classes focused on finding the meaning and one's own place in life. Emphasising the individuality and the integrity of an individual could help young people notice their own high self-worth. Our research indicates that it could help reduce FOMO and the problem of using social media to suppress this fear. Individuals with a sense of their own worth and a specific life plan which they are able to implement or modify despite obstacles are capable of protecting themselves against destructive external influences.

\section{Conflict of interest}

The authors do not report any financial or personal affiliations to persons or organisations that could negatively affect the content of or claim to have rights to this publication.

\section{References}

Abel JP, Buff CL, Burr SA: Social media and the fear of missing out: Scale development and assessment. Journal of Business \& Economics Research (JBER) 2016; 14: 33-44.

Aboujaoude E: Wirtualna osobowość naszych czasów. Mroczna strona e-osobowości. Wydawnictwo Uniwersytetu Jagiellońskiego, Kraków 2012.

Baumeister RF: Meanings of Life. Guilford Press, New York 1991.

Beyens I, Frison E, Eggermont S: "I don't want to miss a thing": adolescents' fear of missing out and its relationship to adolescents' social needs, Facebook use, and Facebook related stress. Comput Human Behav 2016; 64: 1-8.

Boniwell I, Henry J: Developing conceptions of well-being: advancing subjective, hedonic and eudaimonic theories. Social Psychological Review 2007; 9: 3-18.

Borzucka-Sitkiewicz K, Leksy K: Ekshibicjonizm społeczny w Internecie. Motywy i potencjalne zagrożenia dla zdrowia i bezpieczeństwa młodzieży. Wydawnictwo Uniwersytetu Śląskiego, Katowice 2017.

Burke M, Marlow C, Lento T: Social network activity and social wellbeing. In: Proceedings of the SIGCHI Conference on Human Factors in Computing Systems. ACM, New York 2010, April: 1909-1912.

Cieślińska J: Poczucie dobrostanu i optymizmu życiowego kadry kierowniczej placówek oświatowych. Studia Edukacyjne 2013; 27: 95-112.

Crumbaugh JC, Maholick LT: An experimental study in existentialism: the psychometric approach to Frankl's concept of noogenic neurosis. J Clin Psychol 1964; 20: 200-207.

Currie C, Inchley J, Molcho M et al. (eds.): Health Behaviour in Schoolaged Children (HBSC) Study Protocol: Background, Methodology 
and Mandatory Items for the 2013/14 Survey. Child and Adolescent Health Research Unit (CAHRU), St. Andrews University, 2014.

Czerw A, Babiak J: The transformational style of leadership in creating a positive organization. Zarządzanie Zasobami Ludzkimi 2010; 6: 47-60.

Diener E: Subjective well-being. Psychol Bull 1984; 95: 542-575.

Diener E: Subjective well-being. The science of happiness and a proposal for a national index. Am Psychol 2000; 55: 34-43.

Frankl VE: From Death-Camp to Existentialism: A Psychiatrist's Path to a New Therapy. Beacon Press, Boston 1959.

Frankl VE: Logotherapy and existentialism. Psychotherapy: Theory, Research \& Practice 1967; 4: 138-142.

Frankl VE: Man's Search for Meaning. Simon and Schuster, New York 1985.

Frankl VE: The feeling of meaninglessness: a challenge to psychotherapy. Am J Psychoanal 1972; 32: 85-89.

Frankl VE: The Will to Meaning: Foundations and Applications of Logotherapy. Penguin, New York 2014.

Gajda J: Media wytworem i kreatorem współczesnej kultury - kulturowe uwarunkowania mediów. In: Siemieniecki B (ed.): Pedagogika medialna. Podręcznik akademicki. Vol. 1. Wydawnictwo Naukowe PWN, Warszawa 2007: 69-124.

Kasperek-Golimowska E: Nadzieja i optymizm vs zwątpienie i pesymizm w kontekście „dobrego życia” w kulturze konsumpcji. Studia Edukacyjne 2012; 19: 179-213.

Lai C, Altavilla D, Ronconi A et al.: Fear of missing out (FOMO) is associated with activation of the right middle temporal gyrus during inclusion social cue. Comput Human Behav 2016; 61: 516-521.

Lampe CAC, Ellison N, Steinfield C: A familiar face(book): profile elements as signals in an online social network. In: Proceedings of the SIGCHI Conference on Human Factors in Computing Systems. ACM, San Jose 2007, April - May: 435-444.

Mazur J: Obciążenie dolegliwościami subiektywnymi w drugiej dekadzie życia. In: Szymborski J, Zatoński W (eds.): Zdrowie dzieci i młodzieży w wymiarze socjomedycznym. Zdrowie Publiczne. Monografie. Tom II, Wszechnica Polska Szkoła Wyższa w Warszawie, Warszawa 2013: 11-31.

Mazur J (ed.): Zdrowie i zachowania zdrowotne młodzieży szkolnej w Polsce na tle wybranych uwarunkowań socjodemograficznych. Wyniki badań HBSC 2014. Instytut Matki i Dziecka, Warszawa 2015.

Mazur J, Małkowska-Szkutnik A, Oblacińska A et al.: Drabina Cantrila w badaniach stanu zdrowia i nierówności w zdrowiu uczniów w wieku 11-18 lat. Probl Hig Epidemiol 2009; 90: 355-361.

Milyavskaya M, Saffran M, Hope N et al.: Fear of missing out: prevalence, dynamics, and consequences of experiencing FOMO. Motiv Emot 2018; 42: 725-737.
Niśkiewicz Z: Dobrostan psychiczny i jego rola w życiu człowieka. Studia Krytyczne 2016; 3: 139-151.

Oberst U, Wegmann E, Stodt B et al.: Negative consequences from heavy social networking in adolescents: the mediating role of fear of missing out. J Adolesc 2017; 55: 51-60.

Popielski K: Testy egzystencjalne: metody badania frustracji egzystencjalnej i nerwicy noogennej. In: Popielski K (ed.): Człowiek - pytanie otwarte: studia $\mathrm{z}$ logoteorii i logoterapii. Redakcja Wydawnictw KUL, Lublin 1987: 237-261.

Przybylski AK, Murayama K, DeHaan CR et al.: Motivational, emotional, and behavioral correlates of fear of missing out. Comput Human Behav 2013; 29: 1841-1848.

Robertson R: Globalization: Social Theory and Global Culture. SAGE Publications, London, Thousand Oaks, New Dehli 1992.

Ryff CD: Beyond Ponce de Leon and life satisfaction: new directions in quest of successful ageing. Int J Behav Dev 1989; 12: 35-55.

Schulenberg SE, Smith CV, Drescher CF et al.: Assessment of meaning in adolescents receiving clinical services in Mississippi following the Deepwater Horizon Oil Spill: an application of the Purpose in Life Test-Short Form (PIL-SF). J Clin Psychol 2016; 72: 1279-1286

Stead H, Bibby PA: Personality, fear of missing out and problematic internet use and their relationship to subjective well-being. Comput Human Behav 2017; 76: 534-540.

Steger MF, Bundick MJ, Yeager D: Meaning in life. In: Levesque RJR (ed.): Encyclopedia of Adolescence. Springer, New York 2011: 1666-1677.

Zawadzka D, Korzycka M, Oblacińska A: Sense of meaning in life as a factor protecting middle school adolescents from perpetrating and experiencing peer violence. Psychiatr Psychol Klin 2018; 18: 340-353.

Zawadzka D, Stalmach M, Tabak I: Poczucie sensu życia a samoocena zdrowia i osiągnięcia szkolne uczniów w wieku 13-17 lat. Pediatr Pol 2016; 91: 566-573.

Zawadzka D, Stalmach M, Oblacińska A et al.: [Association of the meaning of life with satisfaction, the occurrence of subjective complaints and the family's economic status in the population of lower secondary school students]. Dev Period Med 2017; 21: 60-68.

Zika S, Chamberlain K: On the relation between meaning in life and psychological well-being. Br J Psychol 1992; 83: 133-145. 